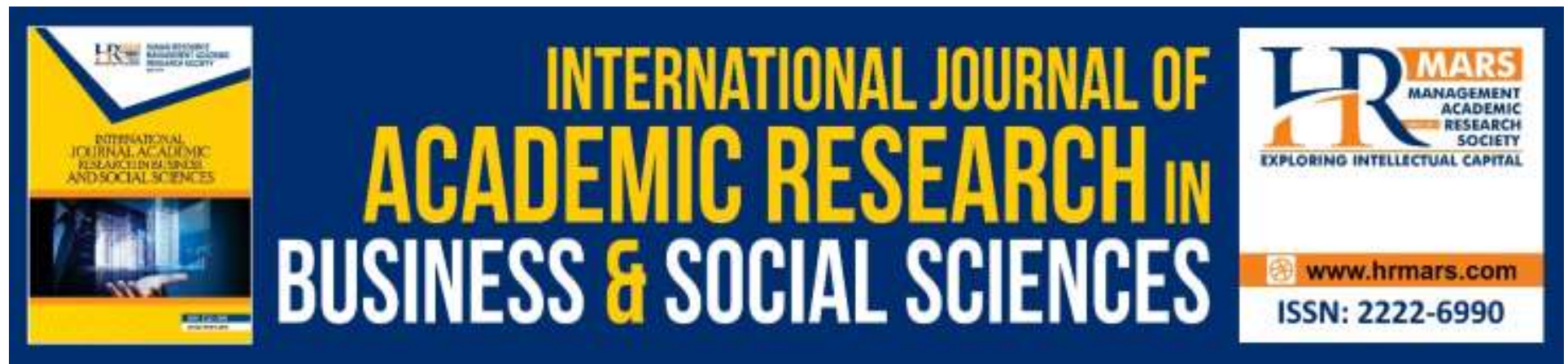

\title{
Tesl Pre-Service Teachers' Tpack: A Review
}

\section{A’tiah Sakinah Abdul Rahman, Raja Nor Safinas Raja Harun}

To Link this Article: http://dx.doi.org/10.6007/IJARBSS/v8-i2/3986

DOI: $10.6007 /$ IJARBSS/v8-i2/3986

Received: 29 Jan 2018, Revised: 20 Feb 2018, Accepted: 25 Feb 2018

Published Online: 26 Feb 2018

In-Text Citation: (Rahman \& Harun, 2018)

To Cite this Article: Rahman, A. S. A., \& Harun, R. N. S. R. (2018). Tesl Pre-Service Teachers' Tpack: A Review. International Journal of Academic Research in Business and Social Sciences, 8(2), 780-789.

Copyright: @ 2018 The Author(s)

Published by Human Resource Management Academic Research Society (www.hrmars.com)

This article is published under the Creative Commons Attribution (CC BY 4.0) license. Anyone may reproduce, distribute, translate and create derivative works of this article (for both commercial and non-commercial purposes), subject to full attribution to the original publication and authors. The full terms of this license may be seen

at: http://creativecommons.org/licences/by/4.0/legalcode

\section{Vol. 8, No.2, February 2018, Pg. $780-789$}

http://hrmars.com/index.php/pages/detail/IJARBSS

JOURNAL HOMEPAGE

Full Terms \& Conditions of access and use can be found at http://hrmars.com/index.php/pages/detail/publication-ethics 


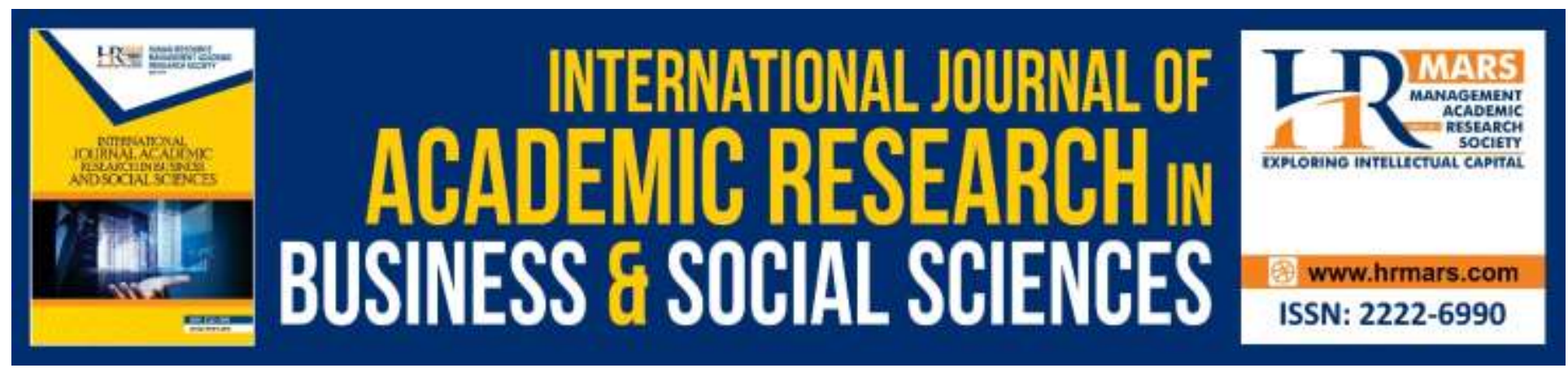

\title{
Tesl Pre-Service Teachers' Tpack: A Review
}

\author{
A'tiah Sakinah Abdul Rahman, Raja Nor Safinas Raja Harun \\ Faculty of Languages and Communication, Universiti Pendidikan Sultan Idris, 35900 Tanjong \\ Malim, Perak, Malaysia
}

\begin{abstract}
The TPACK framework represents a significant role in fostering pedagogical improvement of education in the twenty- first century learning. The use of ICT in twenty first century classroom requires a level of knowledge and expertise of teachers in achieving the learning objectives. A systematic literature review about technology integration and TPACK of 20 journal articles, published between 2011 and 2018 were studied. The purpose of the review is to investigate the technology integration among pre-service teachers and also TPACK Framework among ESL/EFL in teacher education programs. Expected finding shall serve as an improvised integrated model that covers the gap and enhance the TPACK Curriculum framework. Based on the reviews, it provides a number of integral suggestions on for the betterment of TPACK Framework for preservice teachers in teacher education programs and institutions.

Keywords: TPACK, Technology Integration, Pre-Service Teachers, ESL/EFL Pre-Service Teachers
\end{abstract}

\section{Introduction}

The emerging of technologies in education are contributing to the active use of information and communication technology (ICT) among learners (Beetham and Sharpe, 2013; Kalantzis and Cope, 2012; Martinovic and Zhang, 2012)

Jouneau-Sion and Sanchez (2013) have posited the idea that teaching and learning methods should be changed in accordance with the development of technology in $21^{\text {st }}$ century learning. Teachers are required to be more dynamic and creative with relevant teaching content in keeping abreast with current developments. Conventional teaching methods such as "chalk and talk" seems to be less successful to attract students. Consequently, teachers should be prepared to accept the changes and also manage the changes efficiently so that teaching and learning will become more active, interactive, immersive, and challenge-based.

In recent years, the Malaysian government has initiated a number of significant changes in education. The Ministry of Education (MOE) has implemented new policies which prioritize education at all levels including preschool to higher level education. MOE has launched The Malaysia Education Blueprint (MEB) 2013-2025 as an initiative for 21st century learning in 2014. The implementation throughout the country has begun since 2015. There are eleven shifts in MEB 2013-2025 in order to improve and transform the education system which can be embraced 
by all Malaysian including educationists, academics, parents and students (Ministry of Education Malaysia, 2013). One of the shifts in the blueprint is transforming teaching into the profession of choice that can be viewed as an important factor in producing a quality teacher, a crucial aspect in an education system (Ministry of Education Malaysia, 2013). This can contribute to the excellent of schools and students which can be determined by the quality of teachers who are involved in cultivating the knowledge. Therefore, teacher education ought to improve in order to provide competent teachers who are knowledgeable, and have a good teaching skills (Harris \& Sass, 2009).

The 21st century learning brings the revolution in teaching strategies. This positive change is aligned with technological developments and progress of the education system. With the advent of latest technology, it certainly needs the 21st century teachers to improve skills in facilitating the learning process with students who are more educated, entertained and empowered. (Ministry of Education Malaysia, 2015).

\section{Method}

The researcher managed to administer a literature search to gather the journal articles, and some conference papers that characterised the TPACK framework with teacher education programs. In accomplishing this goal, started in March 2017 the initial list included approximately 63 articles listed in Google Scholar. The search continued through the electronic databases such as Taylor and Francis Online, ProQuest New PLatform, and JSTOR. A combined search of Taylor and Francis Online generated 25 references, 20 articles retrieved from ProQuest New Platform and 14 papers yielded from JSTOR.A total 122 papers were retrieved. The search terms included TPACK that retrieved 50 articles; followed by technology integration whereby 25 papers yielded. The third keyword deployed was pre-service teachers retrieved 33 papers and the forth keyword TESL / EFL pre-service teachers retrieved 14 articles. After screening some clone references from various data, the researcher concentrated on the first of 102 articles. After the abstract screening that related to the study, 50 articles were excluded after full screening. Throughout the process of collecting the suitable articles, the researcher discovered many articles incorporated with TPACK but did not describe it for TESL or ESL pre-service teachers. Out of 52 articles that described TPACK integration among pre-service teachers, finally 20 articles described the involvement of TPACK among TESL or EFL pre-service teachers.

\section{Limitation of Study}

The scope is focus on TPACK, and TESL/EFL pre-service teachers.

\section{Review Purpose}

Viewing at the education trend, preparing pre-service teachers by integrating TPACK in teacher education curriculum is crucial because they are required to be proficient with the relevant intelligence towards the process of becoming the outstanding teachers (Mahdum, 2015). This article meant to contemplate specifically on the integration of TPACK among TESL /EFL pre-service teachers. 


\section{Review of Literature}

TPACK

The Technological Pedagogical Content Knowledge (TPACK) framework is a framework that provides an excellent insight into the knowledge that teachers should have to teach effectively with technology (Koehler \& Mishra, 2009). The structure consists of the integration between three domains of knowledge known as technology, pedagogy and content (Mishra \& Koehler, 2006).

TPACK is originally adopted from Schulman's construction in 1986 of Pedagogical Content Knowledge (PCK) by incorporating Technological Knowledge (TK) that is placed along with the Content Knowledge (CK) and pedagogy. Towards its establishment, the acronym of TPCK improved into TPACK to make it easier to remember and to establish integration between the three types of learning (Thomson and Mishra, 2007-2008).

TPACK framework also highlights the comprehension of teachers dealing with technologies that act as the knowledge during teaching and learning. The focus is more on the two combinations of ideas, regarding general pedagogical knowledge and knowledge about content in teacher's teaching, which leads to a new knowledge of delivering the subject distinctively. Currently, in the classroom, it is one of the most significant ways in technological support of the knowledge integration between the three excellent aspects; pedagogy, content and technology (Koehler, Mishra, Kereluik, Shin, \& Graham, 2014).( Refer figure 1)

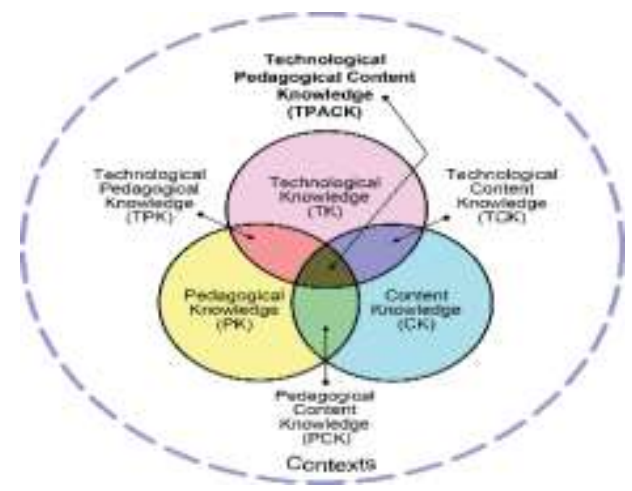

Figure 1. TPACK Framework (Mishra and Koehler, 2006)

\section{TPACK in Teacher Education Program}

Teacher education programmes are responsible to prepare pre-service teachers for technology integration especially for their teaching practices (Coggshall, Bivona, \& Reschly, 2012). Nevertheless, the comprehensive knowledge that should be distributed to pre-service teachers regarding the effectiveness in integrating technology persists a challenge for teacher education programs (Polly \& Brantley-Dias, 2009; Shih-Hsiung, 2012; Shin et al., 2009).

The experience provided by TEP is seen as the dynamic factor inducing new teachers to use technology effectively (Drent and Meelissen, 2008; Agyei and Voogt, 2011). The training they receive will produce great teachers whereby teachers play a compelling part in the acceptance and use of technology in classrooms (Olofsson et al. 2011). Extensive effort has been done to strengthen the integration of technology among pre-service teachers as it is an essential point to an outstanding curriculum technology integration. TPACK should be introduced in teacher 
preparation programs and a central focus of such programs (Han et al. 2013). Once pre-service teachers are familiar with TPACK components, they are better able to accommodate new and changing technologies because they have the initial knowledge needed to guide their technology implementation in their pedagogical knowledge.

\section{English Language Pre-service Teachers and TPACK}

While many studies are focusing on TPACK integration for pre-service teachers as a whole, the researcher feels that it is important to focus on the review involving English language pre-service teachers since the researcher is currently doing a research on it.

The studies focused on TPACK among TESL or EFL pre-service teachers and have been reviewed and identified into several aspects such as the integration of TPACK, implementation of TPACK and assessment related to TPACK among ESL/EFL pre-service teachers (2011-2016). The research methods include 4 categories which are Survey studies, Case studies, Model Development and Instrument Development and Validation. A total of 98 papers were retrieved. After removing duplicate references and the abstract screening that related to the study, the researcher found many articles included references to TPACK but did not describe it for TESL or EFL pre-service teachers. Finally, 12 articles described the involvement of TPACK among TESL or EFL pre-service teachers. The outline of the reviewed papers is listed in Table 2.1:

Table 2.1

Summary of reviewed research papers

(TPACK : TESL/EFL pre-service teachers)

\begin{tabular}{|c|c|c|c|}
\hline No & References & Research Method & Research Approach \\
\hline 1. & $\begin{array}{l}\text { Bostancıoğlu and Handley } \\
\text { (2018) }\end{array}$ & $\begin{array}{l}\text { Development and } \\
\text { Valiodation } \\
\text { Questionnaire }\end{array}$ & Quantiative \\
\hline 2. & Turgut (2017) & $\begin{array}{l}\text { Survey } \\
\text { Open ended }\end{array}$ & Mixed \\
\hline 3. & (Ciptaningrum, 2017) & $\begin{array}{l}\text { Instrument } \\
\text { Development }\end{array}$ & Mixed \\
\hline 4. & Yet and Noordin (2017) & Questionaire & Quantitative \\
\hline 5. & Mei, Brown, and Teo (2017) & $\begin{array}{l}\text { Structural Equation } \\
\text { Model/ Survey }\end{array}$ & Quantitative \\
\hline 6. & Limbong (2016) & $\begin{array}{l}\text { Semi-structure } \\
\text { Interview } \\
\text { Document } \\
\text { e-portfolio }\end{array}$ & Qualitative \\
\hline 7. & Kwangsawad (2016) & $\begin{array}{l}\text { Survey } \\
\text { Lesson Plan } \\
\text { Observation }\end{array}$ & Mixed \\
\hline
\end{tabular}


INTERNATIONAL JOURNAL OF ACADEMIC RESEARCH IN BUSINESS AND SOCIAL SCIENCES

Vol. 8, No.2, February 2018, E-ISSN: 2222-6990 @ 2018 HRMARS

8. (Gökçe Kurt, Akyel, Survey Mixed Koçoğlu, \& Mishra, 2014) observation

9. (Muniandy \& Veloo, 2011) Survey Quantitative

10. (Liu, Liu, Yu, Li, \& Wen, Concept Paper Concept Paper 2014)

11. (Yuen Fook, Sidhu, Kamar, Survey Quantitative \& Abdul Aziz, 2011)

12. Kartchava and Chung Questionnaire Mixed (2015)

13. (Öz, 2015)

14. (Tai, 2013)

15. (Easter, 2012)

Interview

Questionnaire Mixed

Survey Mixed

Document Analysis Qualitative

Observation

interview

16. (Koh \& Divaharan, 2011)

ICT Instructional Model

Qualitative

17. (Sahin, 2011)

Instrument

Quantitative

Development and

Validation

-Survey

18. (Gokce Kurt, Mishra, \& Survey

Quantitative

Kocoglu, 2013)

19. (Charbonneau-Gowdy, Case Study Qualitative 2015)

20. (Ersanli, 2016)

Survey

Mixed

Journal Entries

Based on the reviewed papers, a variety of research methods are found and implemented by 20 respective researchers in the studies on TESL/ EFL pre-service teachers on TPACK.

The use of facebook as a medium of the implementation of Flipped Classroom among eight English pre-service teachers in a study by Limbong (2016) has shown that the approach received a positive feedback. Results revealed that the use of Facebook as a mediator in Flipped Classroom helped pre-service teachers to understand the content learnt, before they had their face to face interaction and discussion in the class. A significant result encourages students to have a constructive feedback on the use of technology in language learning.

A research conducted by Kwangsawad (2016) in Thailand involving 33 pre-service teachers have obtained the high scores in all seven TPACK domains through the survey, lesson plan and observation. Thus, it showed that teacher education programme has succeeded in training the EFL teachers with TPACK knowledge that can be used during their teaching practical and foster their knowledge in integrating technology with lesson planning.

A total of 8 survey studies has been conducted on ESL/EFL pre-service teachers mainly on the development and implementation of TPACK. Yuen Fook et al. (2011) investigated the ICT 
integration. The study involved 70 TESL pre-service teachers who have performed their teaching practicum. The result concluded that these pre-service teachers were positive in incorporating ICT in the teaching strategies. The study suggested teachers should be wise to ICT use in the classroom. Furthermore, Tai (2013) investigated on the impact of CALL workshop by using TPACK as a framework. The outcome of the workshops had a great change and effects on their teaching strategies in an English language class. In addition, a study by Kurt et al. (2013) reported a survey on the subdomains of TPACK for the student teachers in Turkey that had a significant data between the details.

Concurrently, Ersanli (2016) has also explored in improving the TPACK among teacher with 59 TESL trainees. The findings of the study showed a significant improvement in language learning and teaching materials. Oz (2015) also examined the model of TPACK for EFL pre-service teachers' level of TPACK development, explored the combination of content, technology, teaching practices for quality classroom lessons. On the other hand, a survey on self-assessment was developed by Baser et al. (2015). The survey reviewed on the assessment tool that addresses specifically technologies with subjects learnt. Then, Yet and Noordin (2017) has conducted a study on the use of ICT among Tesl pre-service teachers. The study with purposively 46 pre-sevice teachers showed that pre-service teachers were confidence and skillful to integrate the technology in their teaching.

As for Muniandy and Veloo (2011), a study by using a questionnaire was conducted based on using online video clips. The result recommended that that pre service teachers were please and confidence to use online platform in their teaching. whereby TPACK as a theoretical framework assists in technology integration among the pre-service teachers. Turgut (2017) conducted a study with 176 English preservice teachers through a TPACK Survey and the study provided different pattern of TPACK development in a four year long teacher education programme. Based on the result, recommendations invoved policy makers, teacher educators were made. Mei et al. (2017) has conducted a study regarding the use of computer in language language learning purposes in China involving $295 \mathrm{EFL}$ pre-service teachers.it revealed that the aspects of facilitating conditions would be able to improve on the acceptance of technology integration through (CALL) in China. As for Kartchava and Chung (2015), the study investigated on the beliefs of using technology digitally during class lesson among English pre-service teachers. The results showed that the participants were complacent towards technology usage.

There are three case studies conducted for ESL/EFL pre-service teachers. The first case study has been conducted by Kurt et.al (2014) of the three main aspects in TPACKthe during planning and lesson implementation. The result found out that the teaching practice that they have gone through helped those trainees to comprehend their TPACK development. Another case study by Easter (2012) reviewed how a teacher education program uses the TPACK framework when technology has been guided to pre-service teachers. The result of this study has revealed that TPACK Framework act as a guide with recommendations on promoting technology literacy in pre-service teachers. On the other hand, Charbonneau-Gowdy (2015) has examined the best practice in teacher education program in using technology model and promoting best practices in their classroom. The findings suggested pre-service teachers need the support and 
involvement of larger teacher education program community as for them to integrate successful technology integration in the classroom.

There is one study which employs model development method by Koh and Divaharan (2011). The model further explained an instructional procedure for preparing pre-service teachers (TPACK). It explored three phases for developing teachers' TPACK through ICT instruction. It involved the stages of the teachers' acceptance and technical proficiency, modelling and applying the knowledge of pedagogy. The findings suggested that more emphasis should be given on modelling the pedagogical approach, reviewing the product and sharing among the peers.

There are three papers reviewed on instrument development and validation. Sahin (2011) has carried out a research on the development of (TPACK) survey. The survey involves each related category in building the TPACK model: The results reported the TPACK survey has reliable dimension. Ciptaningrum ( 2017) designed a survey instrument to examine the ICT learning experience and the TPACK knowledge among English pre-service teachers. The instruments have succesfully considered acceptable to be used in examining the ICT Usage among pre-service teachers learning experience and the development of TPACK.Bostancıoğlu and Handley (2018) introduced a self-report questionnaire to access TPACK for English Language Teaching with 542 EFL Teachers. The results showed an encouraging approach to integrate English Language learning with technologies.

Therefore, TPACK can be suggested to be known as a theoretical framework, which can be practised by pre-service teachers to conjoin technology in their teaching. Teacher's knowledge regarding technology should be varied and the combination of technology, pedagogy, and content in the classroom should be fully optimized between one and another. Many of the researchers above has reviewed and recommended integrating TPACK across the teacher education institution's curriculum, and support pre-service teachers with the possibility to experience ICT that can support teaching within specific content areas. (Voogt, Fisser, Pareja Roblin, Tondeur, \& van Braak, 2013). From the review, the studies have contributed to the further development of the concept of TPACK. Current TPACK research about the theoretical conceptualization of TPCK includes efforts that needs an exploration to augment the extant of TPACK theoretical framework. The complexity of technology integration should be addressed.

The studies also explore on how TPACK is integrated (using and managing technology with pedagogical approach and content knowledge) among TESL or EFL pre-service teachers at the certain countries which English Language is second or foreign language in the countries. However, there is still a lack of further research on TPACK being conducted among TESL preservice teachers in Asian countries. Thus, a study should be carried out to address this issue in the future.

\section{Acknowledgement}

A special thanks to the education grant, Niche Research Grant Scheme (NRGS): Project 1: (Curriculum 2014-0001-107-82-1) of Sultan Idris Educational University (UPSI) with the Project 
INTERNATIONAL JOURNAL OF ACADEMIC RESEARCH IN BUSINESS AND SOCIAL SCIENCES

Vol. 8, No.2, February 2018, E-ISSN: 2222-6990 @ 2018 HRMARS

Leader: Associate Professor Dr. Raja Nor Safinas Raja Harun for her great help in preparing the chapter.

\section{Corresponding Author}

A'tiah Sakinah Abdul Rahman

Faculty of Languages and Communication,

Universiti Pendidikan Sultan Idris,

35900 TanjongMalim, Perak, Malaysia

Email: atiah.sakinah5@gmail.com

\section{References}

Bostancıoğlu, A., \& Handley, Z. (2018). Developing and validating a questionnaire for evaluating the EFL 'Total PACKage': Technological Pedagogical Content Knowledge (TPACK) for English as a Foreign Language (EFL). Computer Assisted Language Learning, 1-27.

Charbonneau-Gowdy, P. (2015). It Takes a Community to Develop a Teacher: Testing a New Teacher Education Model for Promoting ICT in Classroom Teaching Practices in Chile. Electronic Journal of e-Learning, 13(4), 237-249.

Ciptaningrum, D. S. (2017). The Development of the Survey of Technology Use, Teaching, and Technology-Related Learning Experiences among Pre-Service English Language Teachers in Indonesia. Journal of Foreign Languange Teaching and Learning, 2(2), 11-26.

Coggshall, J. G., Bivona, L., \& Reschly, D. J. (2012). Evaluating the Effectiveness of Teacher Preparation Programs for Support and Accountability. Research \& Policy Brief. National Comprehensive Center for Teacher Quality.

Easter, T. N. (2012). Preparing pre-service teachers and technology literacy. Washington State University.

Ersanli, C. Y. (2016). Improving Technological Pedagogical Content Knowledge (TPACK) of PreService English Language Teachers. International Education Studies, 9(5), 18.

Harris, D. N., \& Sass, T. R. (2009). What Makes for a Good Teacher and Who Can Tell? Working Paper 30. National Center for Analysis of Longitudinal Data in Education Research.

Jouneau-Sion, C., \& Sanchez, E. (2013). Preparing schools to accommodate the challenge of Web 2.0 technologies. Education and Information Technologies, 18(2), 265-270.

Kartchava, E., \& Chung, S. (2015). Pre-Service and In-Service English as a Second Language Teachers' Beliefs about the Use of Digital Technology in the Classroom. Studies in English Language Teaching, 3(4), 355.

Koehler, M. J., Mishra, P., Kereluik, K., Shin, T. S., \& Graham, C. R. (2014). The technological pedagogical content knowledge framework Handbook of research on educational communications and technology (pp. 101-111): Springer.

Koh, J. H., \& Divaharan, H. (2011). Developing pre-service teachers' technology integration expertise through the TPACK-developing instructional model. Journal of Educational Computing Research, 44(1), 35-58.

Kurt, G., Akyel, A., Koçoğlu, Z., \& Mishra, P. (2014). TPACK in practice: A qualitative study on technology integrated lesson planning and implementation of Turkish pre-service teachers of English. ELT Research Journal, 3(3), 153-166. 
Kurt, G., Mishra, P., \& Kocoglu, Z. (2013). Technological pedagogical content knowledge development of Turkish pre-service teachers of English. Paper presented at the meeting of the Society for Information Technology and Teacher Education, New Orleans, LA. Retrieved from http://punya. educ. msu. edu/wpcontent/uploads/2013/03/Kurt-MishraSITE2013-paper. pdf.

Kwangsawad, T. (2016). Examining EFL Pre-service Teachers' TPACK trough Self-report, Lesson Plans and Actual Practice. Journal of Education and Learning (EduLearn), 10(2), 103-108.

Limbong, E. (2016). The Voices of Preservice EFL Teachers on the Implementation of Teacher Educators '. IJEE (Indonesian Journal of English Education), 3(2), 171-191.

Liu, S., Liu, H., Yu, Y., Li, Y., \& Wen, T. (2014). TPACK: A new dimension to EFL teachers' PCK. Journal of Education and Human Development, 3(2), 681-693.

Mahdum, M. (2015). Technological Pedagogical and Content Knowledge (TPACK) of English Teachers in Pekanbaru, Riau, Indonesia. Mediterranean Journal of Social Sciences, 6(5), 168.

Mei, B., Brown, G. T., \& Teo, T. (2017). Toward an Understanding of Preservice English as a Foreign Language Teachers' Acceptance of Computer-Assisted Language Learning 2.0 in the People's Republic of China. Journal of Educational Computing Research, 0735633117700144.

Muniandy, B., \& Veloo, S. (2011). Managing and utilizing online video clips for teaching English language: Views of TESOL pre service teachers. Paper presented at the 2 nd International Conference on Education and Management Technology IPCSIT.

Öz, H. (2015). Assessing Pre-service English as a Foreign Language Teachers' Technological Pedagogical Content Knowledge. International Education Studies, 8(5), 119.

Sahin, I. (2011). Development of survey of technological pedagogical and content knowledge (TPACK). TOJET: The Turkish Online Journal of Educational Technology, 10(1).

Tai, S.-J. D. (2013). From TPACK-in-action workshops to English classrooms: CALL competencies developed and adopted into classroom teaching.

Turgut, Y. (2017). Tracing preservice English language teachers' perceived TPACK in sophomore, junior, and senior levels. Cogent Education, 4(1), 1368612.

Voogt, J., Fisser, P., Pareja Roblin, N., Tondeur, J., \& van Braak, J. (2013). Technological pedagogical content knowledge-a review of the literature. Journal of Computer Assisted Learning, 29(2), 109-121.

Yet, T. S., \& Noordin, N. B. (2017). The Use of ICT among Pre-Service English Language Teachers. International Journal of English Language Education, 5(1), 100-112.

Fook, Y. C., Sidhu, G. K., Kamar, N., \& Abdul Aziz, N. (2011). Pre-Service Teachers' Training in Information Communication and Technology for the ESL Classrooms in Malaysia. Turkish Online Journal of Distance Education, 11(3), 97-108. 